\title{
British Multinationals in South East Asia: Strategy, Subsidiaries and Performance
}

\author{
Quyen T.K. Nguyen
}

Ph.D. awarded by the University of Reading, Henley Business School, July 2012

ThIS Dissertation aIMS to CONTRIBUte to the theoretical and empirical literature of the multinational subsidiary strategy and performance. First, this study adopts an innovative approach to theory development by integrating internalization theory (Buckley \& Casson, 1976; Hennart, 1982; Rugman, 1981) in the international business literature with the pecking order theory on capital structure and financing sources in the finance literature (Myers \& Majluf, 1984). Second, the focus on testing the performance of subsidiaries has led this research to advance on the theoretical concept of subsidiary-specific advantages (SSAs) as developed by Birkinshaw (1997) and by Rugman and Verbeke (2001). These concepts have not been tested in any systematic way for emerging economies. Third, this research focuses on the recombination capability which is the highest-order firm-specific advantages (FSAs) in economic value creation in an international environment (Verbeke, 2009; Rugman, Verbeke \& Nguyen, 2011). Specifically, this dissertation has three empirical studies:

1. Subsidiary-specific advantages (SSAs), governance and performance

2. Host country market attractiveness, subsidiary-specific advantages (SSAs) and performance

3. Multinational subsidiaries as flagship firms and the fast moving consumer goods sectors: Unilever in South East Asia

Drawing upon the economic theories of the multinational enterprise (MNE) which are internalization theory (Buckley \& Casson, 1976; Hennart, 1982; Rugman, 1981), Dunning's Ownership, Internalization and Location (OLI) framework and his four foreign direct investment (FDI) motives (Dunning, 1998) to maximize the net present value (NPV) of firm-specific advantages (FSAs) by optimal operations of the dispersed network of subsidiaries, I develop a conceptual framework and then test a set of hypotheses.

The hypotheses were tested using a unique primary dataset collected by a questionnaire survey with 101 British MNE subsidiaries across six emerging economies in the South East Asian region (Malaysia, Indonesia, the Philippines, Singapore, Thailand and Vietnam) over five-year period (2003-2007). Managerial insights were obtained through interviews with subsidiary managers, in direct observations of the daily operations of subsidiaries during the pilot test period and follow-up e- mail interactions with subsidiary managers during data collection. The findings of the survey were communicated to participating subsidiary managers. The report received strong interests, feedback and comments from subsidiary managers. Survey data has been supplemented with secondary data of annual reports of parent firms.

The survey was based on principles of modern international business theories which were translated into managerial concepts such that managers could identify the mechanism by which they undertook recombination of firm-specific advantages (FSAs) with host countryspecific advantages (host CSAs). Additionally, international accounting standards (IAS24 related party disclosure and IFRS8 operating segments) were incorporated in the questionnaire design. Thus, I discovered the nature and the extent of subsidiary sales across three new dimensions: first, by markets (domestic sales and exports); second, by geographic areas (sales to the Asia Pacific region and sales to rest of the world); and third by customer types (sales to external customers and intra-firm sales).

\section{Subsidiary-specific advantages (SSAs), governance and performance}

SSAs include internal financing, subsidiary general management and marketing capabilities. Governance refers to the parent-subsidiary relationship, namely, subsidiary autonomy, subsidiary level of national responsiveness by offering regionally and/or locally customized products and services, ownership and control through wholly owned foreign subsidiaries (WOFSs) versus joint venture (JVs). Subsidiary performance is evaluated using subsidiary managers' perception on financial and non-financial criteria of actual performance against budget of sales growth, profit growth, return on capital employed (ROCE) and market share growth compared to competitors.

The main theoretical contribution of this study is to establish that internal financing is a type of firm-specific advantage (FSA), but one largely under-researched in the international business literature. This study also contributes to the theory of the MNE with its focus on the reality of the internal capital markets in financing foreign subsidiaries. There are three significant findings. First, internal financing acts as an FSA to enhance subsidiary performance. I find that 93 percent of financing sources in 
the British subsidiaries (including capital investment from parent firms) come from internal financing, which is fully consistent with the "pecking order theory." The two traditional SSAs and subsidiary level of national responsiveness by offering regionally and locally customized products and services have positive impacts on subsidiary performance. Second, governance in terms of subsidiary autonomy, ownership and control through wholly-owned foreign subsidiary (WOFS) versus joint venture (JV) does not affect subsidiary performance. This is somewhat surprising given the large literature on entry mode choice. This issue is investigated further by a comparative analysis of the characteristics and performance between wholly-owned foreign subsidiaries (WOFSs) and joint ventures (JVs) using a Kruskal Wallis test. Third, there are no significant differences between the two groups and they perform equally.

\section{Host country location, subsidiary-specific advan- tages (SSAs) and performance}

This study examines the relationship of host country market attractiveness, subsidiary-specific advantages (SSAs), subsidiary sales and asset exploitation foreign direct investment (FDI) motives as they affect subsidiary performance. There are three significant findings. First, host country market attractiveness, export sales by a subsidiary besides servicing domestic markets, asset exploitation foreign direct investment (FDI) motives, and subsidiary-specific advantages (SSAs) have a statistically significant positive impact on performance of subsidiaries. Second, market-seeking is the predominant foreign direct investment (FDI) motive (66 percent). Third, these subsidiaries explicitly focus on sales to external customers where they generate on average 91 percent of their total sales. Sales to the Asia Pacific region account for 95 percent of total sales. The contribution of domestic sales and exports are at 77 percent and 23 percent accordingly.

Because the direction of causality is hard to assess with certainty in the first two empirical studies, I examine the reverse effects of subsidiary profits on subsidiary-specific advantages (SSAs). I find that 84 percent of subsidiaries in the sample are profitable over the five-year period 2003-2007. A part of the profits has been reinvested into subsidiaries' business for subsequent expansion and growth through retained earnings. Thus, these subsidiaries can use the financial resources to continue enhancing their existing firm-specific advantages (FSAs) and developing new firm-specific advantages (FSAs). I find a positive relationship on the reverse effects. This is the first study which has empirically tested such reverse effects due to its new and innovative approach to apply accounting and financial reporting to international business.

\section{Multinational subsidiaries as flagship firms and the fast moving consumer goods sector: Unilever in South East Asia}

This study conducts a major case study of Unilever's subsidiaries in Indonesia and Vietnam to establish the extent to which they generate new subsidiary-specific advantages (SSAs). I find evidence that subsidiary managers generate subsidiary-specific advantages (SSAs) by recombining the firm-specific advantages (FSAs) of their parent firm with newly developed firm-specific advantages (FSAs) by subsidiaries obtained in interacting with host country-specific advantages (CSAs). They do this principally through the development of 'flagship strategy' (Rugman \& D'Cruz, 2000). This strategy aims to access complementary resources of external actors in the host countries through establishing network relationships with key partners in the value chains such as key suppliers, key distributors, selected key competitors and institutions in the non-business infrastructure. I find that flagship strategy is a type of network capabilities that can lead to firm-specific advantages (FSAs) for the multinational enterprise (MNE). It also contributes to the performance of the subsidiaries and help develop local networks of small and medium enterprises (SMEs) which enhance economic development.

\section{Contributions}

This dissertation contributes to the literature of subsidiary strategy and performance in several new ways. First, this study is among the first to examine internal financing as a recombination capability which enhances the performance of the foreign subsidiaries of the MNE. Consistent with internalization theory, internal financing is conceptually just as valuable as other traditional firm-specific advantages (FSAs) in R\&D, marketing and managerial skills. The firm-specific advantage (FSA) of internal financing, although driven by the parent firm (and its costs of

\section{Bs The three empirical studies provide strong evidence that subsidiary performance depends on subsidiary-specific adoantages ( $S \circlearrowleft$ As). Thus, they support internalization theory.}

capital due to the advantages of consolidated accounting returns) is one of most benefit to the subsidiary. This firm-specific advantage (FSA) (like all others) arises due to recombinations with country-specific advantages (CSAs).

Second, this study advances on the concept of subsidiary-specific advantages (SSAs) of the theory of the MNE. While Rugman \& Verbeke (2001) have developed the concept by outlining how such FSAs are created by foreign subsidiaries, I test how they affect subsidiary performance. The three empirical studies provide strong evidence that subsidiary performance depends on subsidiary-specific advantages (SSAs). Thus, they support internalization theory. 
Third, this research emphasizes the recombination capability of the subsidiary. The empirical results show that the subsidiary is the engine to recombine internationally transferable firm-specific advantages (FSAs) from parent firms with newly developed firm-specific advantages (FSAs) by subsidiaries and complementary resources of external actors in host countries.

Finally, this research provides important managerial implications. These include proactive strategies for long-term sustainable and profitable growth of foreign subsidiaries, such as using internal funds to finance subsidiary expansion, and subsidiary sales with strong focus on external customers in the broad Asia Pacific region.

The policy implications of this research reach beyond the business arena. This study provides insights to policy makers on the role of subsidiaries in facilitating economic and social development when the links between subsidiaries and local small and medium-sized enterprises (SMEs) in the flagship networks are examined.

The findings of this research contribute to the teaching philosophy of international business (IB) as an inter-disciplinary subject. By integrating IB with accounting and finance, this research demonstrates that the teaching and learning on the strategy and performance of the MNE and its foreign subsidiaries is based upon rigorous theories and relevant empirical evidence in real world business realities. Further, the ASEAN regional context (ASEAN: the Association of South East Asian Nations) is a dynamic business environment for research and teaching of IB. This research focuses on managerial approach with strong emphasis on factors which are under control of subsidiary mangers. Thus, it promotes the accessibility, practicality and development of lifelong learning skills for the benefits of management students.

\section{References}

Birkinshaw, J.M. 1997. Entrepreneurship in multinational corporations: The characteristics of subsidiary initiatives. Strategic Management Journal, 18(3): 207-229.

Buckley, P. \& Casson, M. C. 1976. The future of multinational enterprise. Basingstoke and London: Macmillan.

Dunning, J.H. 1998. Location and the multinational enterprise: A neglected factor? Journal of International Business Studies, 29: 4566.

Hennart, J.F. 1982. A theory of multinational enterprise. Ann Arbor, University of Michigan Press.

Myers, S. \& Majluf, N. 1984. Corporate financing and investment decisions when firms have information that investors do not have. Journal of Financial Economics, 13: 187-222.

Nguyen, Q.T.K. 2013. The regional strategies of British multinational subsidiaries in South East Asia. British Journal of Management, forthcoming, DOl 10.1111/1467-8551.1.12006.
Nguyen, Q.T.K. 2013. Can British multinational enterprises finance economic development in South East Asia. Multinational Business Review, 21 (2): forthcoming.

Nguyen, Q.T.K. 2010. The empirical literature on multinational enterprises, subsidiaries and performance. Multinational Business Review, 19(1): 47-63.

Rugman, A.M, Verbeke, A \& Nguyen, Q. T.K. 2011. Fifty years of international business and beyond. Management International Review, 51(6): 755-786.

Rugman, A.M. 1981. Inside the multinationals: The economics of internal markets, New York: Columbia University Press.

Rugman, A.M. \& D'Cruz. J. 2000. Multinationals as flagship firm: Regional business networks. Oxford, New York: Oxford University Press.

Rugman, A.M. \& Verbeke, A. 2001. Subsidiary-specific advantages in multinational enterprises. Strategic Management Journal, 22: $237-250$.

Verbeke, A. 2009. International business strategy. Cambridge: Cambridge University Press.

Quyen T.K. Nguyen is a Lecturer in International Business and Strategy at Henley Business School, the University of Reading. Her research focuses on multinational subsidiary strategy and performance. Her Ph.D thesis was awarded the 2012 Michael Z. Brooke Prize for The Best Doctoral Paper at the $39^{\text {th }}$ AIB UK \& Ireland Conference. She has published in refereed journals, including British Journal of Management, Management International Review and Multinational Business Review and in edited volume. 